\title{
Effects of a combined therapy of bortezomib and ionizing radiation on chondrosarcoma three-dimensional spheroid cultures
}

\author{
BIRGIT LOHBERGER $^{1}$, DIETMAR GLAENZER ${ }^{1,2}$, NICOLE ECK ${ }^{1,2}$, BIBIANE STEINECKER-FROHNWIESER $^{2}$, \\ ANDREAS LEITHNER ${ }^{1}$, BEATE RINNER ${ }^{3}$, SYLVIA KERSCHBAUM-GRUBER ${ }^{4}$ and DIETMAR GEORG ${ }^{4,5}$ \\ ${ }^{1}$ Department of Orthopedics and Trauma, Medical University of Graz, A-8036 Graz; \\ ${ }^{2}$ Department for Rehabilitation, Ludwig Boltzmann Institute for Arthritis and Rehabilitation, A-5760 Saalfelden; \\ ${ }^{3}$ Division of Biomedical Research, Medical University of Graz, A-8036 Graz; ${ }^{4}$ Department of Radiation Oncology, \\ Medical University of Vienna, A-1090 Vienna; ${ }^{5}$ MedAustron Ion Therapy Center, A-2700 Wiener Neustadt, Austria
}

Received September 24, 2020; Accepted March 3, 2021

DOI: 10.3892/ol.2021.12689

\begin{abstract}
Chondrosarcomas represent a heterogeneous group of primary bone cancers that are characterized by hyaline cartilaginous neoplastic tissue and are predominantly resistant to radiation and chemotherapy. However, adjuvant radiotherapy is often recommended in inoperable cases or after incomplete resections. To improve the efficiency of treatment, the present study tested a combination therapy with ionizing radiation (IR) and the proteasome inhibitor bortezomib. Using a three-dimensional (3D) spheroid model, 0-20 Gy of IR was applied to chondrosarcoma cells and healthy human chondrocytes. Following combined treatment with IR and bortezomib, the cell cycle distribution, apoptotic induction, the survivin pathway, autophagy and DNA damage were evaluated. Both cell types exhibited a slight decrease in viability following increasing doses of IR; the chondrosarcoma cells demonstrated a significant dose-dependent increase in the expression levels of the DNA damage marker histone H2AX phosphorylation at serine $139(\gamma \mathrm{H} 2 \mathrm{AX})$. The combination treatment with bortezomib significantly decreased the cell viability after $48 \mathrm{~h}$ compared with that in irradiated cells. High-dose IR induced $\mathrm{a}_{2} / \mathrm{M}$ phase arrest, which was accompanied by a decrease in the number of cells at the $\mathrm{G}_{1}$ and $\mathrm{S}$ phase. Co-treatment with bortezomib changed the distribution of the cell cycle phases. The mRNA expression levels of the proapoptotic genes Bcl-2-associated X protein (Bax) and Bak were significantly increased by bortezomib treatment and combination therapy with IR. In addition, the combination therapy resulted in a synergistic decrease of the expression levels of survivin and its corresponding downstream pathway molecules, including
\end{abstract}

Correspondence to: Dr Birgit Lohberger, Department of Orthopedics and Trauma, Medical University of Graz, Auenbruggerplatz 5-7, A-8036 Graz, Austria

E-mail: birgit.lohberger@medunigraz.at

Key words: chondrosarcoma, bortezomib, ionizing radiation, cell cycle arrest, survivin pathway heat shock protein 90, X-linked inhibitor of apoptosis protein, smad 2 and smad 3. Comparative analyses of $\gamma \mathrm{H} 2 \mathrm{AX}$ at 1 and $24 \mathrm{~h}$ post-IR revealed efficient DNA repair in human chondrosarcoma cells. Therefore, additional bortezomib treatment may only temporarily improve the radiation sensitivity of chondrosarcoma cells. However, the inhibition of the survivin pathway by the combined treatment with IR and bortezomib, observed in the present study, revealed a novel aspect in the tumor biology of chondrosarcoma 3D spheroid cultures and may represent a potential target for therapy.

\section{Introduction}

Chondrosarcomas are heterogeneous, mostly slow-growing, primary malignancies of the bone that are characterized by hyaline cartilaginous neoplastic tissue formation $(1,2)$. Surgery remains the gold standard, although macroscopically complete resection is often impeded by the presence of adjacent critical structures. Therefore, adjuvant or definitive radiotherapy is frequently recommended for inoperable cases or following incomplete resection (3-8).

Particle radiotherapy with protons and carbon ions has emerged as a novel therapy option and has been demonstrated to be beneficial in the treatment of chondrosarcomas. The physical and biological characteristics of particles provide the possibility to deliver higher doses to larger target volumes while adhering to the tolerance doses of normal tissue structures surrounding the tumor (9-11). However, these complex technologies are only available at a limited number of particle radiation centers worldwide; thus, patient access is highly restricted. Therefore, it is crucial to optimize widely available photon therapy treatment despite lower therapeutic success. Specific focus should be drawn to combinatorial approaches with chemotherapeutics.

Previous studies have demonstrated a synergistic effect of the proteasome inhibitor bortezomib and ionizing radiation (IR) on the viability of various types of cancer, including oral (12), cervical (13) and colorectal (14) cancer, as well as esophageal squamous cell carcinoma (15), and suggested a radiosensitizing effect of bortezomib. The proteasome pathway serves an essential role in the regulation of a variety of cellular 
processes associated with the proliferation and survival of tumor cells (12-15). Our previous study demonstrated that bortezomib exhibits antitumor activity against chondrosarcoma cells (16).

Cell-based assays are the key tool to assess the potential efficacy of new treatment options in cancer research. Cellular heterogeneity, morphology and the interactions of cells grown in three-dimensional (3D) cultures are similar to the in vivo microenvironment (17). 3D spheroids are formed from cells in a variety of stages, including proliferating, quiescent, hypoxic, apoptotic and necrotic cells (18). The outer spheroid layer, which is exposed the most to the medium, is mostly comprised of proliferating cells (19). Thus, the cellular processes of these cells mimic those occurring in vivo (20). Therefore, the present study used the 3D spheroid model for the experiments.

This aim of the present study was to determine the potential radiosensitizing effects of concomitant bortezomib treatment in human chondrosarcoma 3D spheroid cultures and to elucidate the underlying cellular processes.

\section{Materials and methods}

$3 D$ spheroid cultures. Chondrosarcoma SW1353 cells (ATCC ${ }^{\circledR}$ HTB-94 ${ }^{\mathrm{TM}}$; LGC Standards, Ltd.) were cultured in Dulbecco's modified Eagle's medium (DMEM-F12) supplemented with $10 \%$ fetal bovine serum (FBS), $1 \%$ L-glutamine, $1 \%$ penicillin/streptomycin and $0.25 \mu \mathrm{g}$ amphotericin B (all Gibco; Thermo Fisher Scientific, Inc.). Human healthy chondrocytes (HCs) (cat. no. 402-05a; Cell Applications, Inc.) were cultured in DMEM-F12 supplemented with $10 \%$ FBS, $1 \% \mathrm{~L}$-glutamine, $1 \%$ penicillin/streptomycin, $0.25 \mu \mathrm{g}$ amphotericin B, TGF $\beta 3$ and FGF $\beta$ (both $1 \mathrm{ng} / \mathrm{ml}$; Sigma-Aldrich; Merck KGaA). The SW1353 cell line was verified by short tandem repeat analysis utilizing a PowerPlex ${ }^{\mathrm{TM}} 16$ System kit (Promega Corporation). The primary chondrocytes were used between passages 2 and 4. Regular testing for mycoplasma infection was conducted by PCR. Cells were incubated at $37^{\circ} \mathrm{C}$ in a humidified atmosphere with $5 \% \mathrm{CO}_{2}$ and passaged by trypsinization upon reaching confluence. 3D spheroids were generated by the hanging drop method. A total of 5,000 cells/spheroid mixed with 1.2\% Methocel A4M (Sigma-Aldrich; Merck KGaA) dissolved in the culture medium were placed on the cover of a petri dish and incubated upside-down for $48 \mathrm{~h}$ at $37^{\circ} \mathrm{C}$ in a humidified atmosphere with $5 \% \mathrm{CO}_{2}$. Subsequently, the spheroids were transferred to appropriate culture plates. To avoid adhesion of the spheroid cultures, $1 \%$ poly(2-hydroxyethyl methacrylate)-coated plates were used.

Hematoxylin and eosin stain. For histological and immunohistochemical evaluation, the chondrosarcoma 3D spheroids were fixed for 30 min with $10 \%$ formalin (Carl Roth $\mathrm{GmbH}$ ) at room temperature and embedded in paraffin. For morphological evaluation, staining with hematoxylin and eosin was performed. Briefly, following a 15-min incubation in xylene (Merck KGaA) and a descending ethanol series (100,90, 70 and $50 \% ; 3$ min each), the sections were stained with hematoxylin and eosin for 2 min each at room temperature. The embedding of the samples was performed with n-buthyl-acetate and Entellan $^{\circledR}$ (both Merck KGaA).
$X$-ray irradiation. X-ray irradiation was performed at the Division of Biomedical Research, Medical University Graz (Graz, Austria) with an RS-2000 biological irradiator (RadSource Technologies, Inc.) equipped with a 3-mm $\mathrm{Al} / 0.3-\mathrm{mm} \mathrm{Cu}$ filter and a current of $25 \mathrm{~mA}$ to provide $160 \mathrm{kV}$ $\mathrm{X}$-rays at a dose rate of $2.108 \mathrm{~Gy} / \mathrm{min}$.

Cell viability assay. For the dose-response relationship, 100 spheroids each of HC and SW1353 were pretreated with the $\mathrm{IC}_{50}$ concentration of $5 \mathrm{nM}$ bortezomib (Selleck Chemicals) for 24 h. Cell viability was determined with the CellTiter-Glo ${ }^{\circledR} 3 \mathrm{D}$ Cell Viability assay (Promega Corporation) at 3 and $48 \mathrm{~h}$ post-administration of 0 (control) to $20 \mathrm{~Gy}$ IR. Background reference values were derived from the culture media. Absorbance was measured with a LUMIstar ${ }^{\mathrm{TM}}$ microplate luminometer (BMG Labtech $\mathrm{GmbH})$, and the mean $\pm \mathrm{SD}$ was calculated (HC, $\mathrm{n}=3$; SW1353, $\mathrm{n}=7$; performed in biological quadruplicates).

Cell cycle analysis. Following pretreatment with $5 \mathrm{nM}$ bortezomib and treatment with 0,5 or $20 \mathrm{~Gy}$ IR, spheroid cultures were harvested at 3 and $48 \mathrm{~h}$. A single-cell suspension was prepared by trypsinization, and cells were fixed with $70 \%$ ice-cold ethanol for $10 \mathrm{~min}$ at $4^{\circ} \mathrm{C}$. Prior to flow cytometry, the cell pellet was resuspended in PI-staining buffer $(50 \mu \mathrm{l} / \mathrm{ml}$ PI, $100 \mu \mathrm{l} / \mathrm{ml}$ RNAse A, $0.1 \%$ Triton X-100 and $0.1 \%$ sodium citrate) and incubated for $20 \mathrm{~min}$ at room temperature. Cell cycle distribution was measured with a CytoFlexLX flow cytometer (Beckman Coulter, Inc.) and analyzed using ModFit LT software Version 4.1.7 (Verity software house).

Annexin V/PI apoptosis assay. To detect translocated phosphatidylserine, the eBioscience ${ }^{\mathrm{TM}}$ FITC Annexin V Apoptosis Detection kit (Thermo Fisher Scientific, Inc.) was used $48 \mathrm{~h}$ after treatment with IR and/or bortezomib according to the manufacturer's instructions. Flow cytometry analysis was performed with a CytoFlexLX flow cytometer, and a total of 10,000 events were collected. Cells were identified in the side and forward scatter with a linear scale. Fluorescence signals were presented with a logarithmic scale. Compensation was performed by single Annexin and PI measurements, and analyzed by FCS3 express software Version 7 (De Novo Software, LLC). The graphical representations of Annexin ${ }^{-} / \mathrm{PI}^{-}$ (viable cells), Annexin ${ }^{+} / \mathrm{PI}^{-}$(early apoptotic cells), Annexin ${ }^{+} / \mathrm{PI}^{+}$ (late apoptotic cells) and Annexin $/ \mathrm{PI}^{+}$(necrotic cells) were plotted as stacked bars $(n=3)$.

Reverse transcription-quantitative $(R T-q) P C R$. Total RNA was isolated following bortezomib pretreatment and $48 \mathrm{~h}$ post-5 Gy IR from spheroid cultures using the RNeasy Mini kit (Qiagen $\mathrm{GmbH}$ ) and DNase-I treatment according to the manufacturer's instructions. A total of $1 \mu \mathrm{g}$ RNA was reverse-transcribed with an iScript cDNA Synthesis kit, (Bio-Rad Laboratories, Inc.) using a blend of oligo(dT) and random hexamer primers. Amplification was performed with the SsoAdvanced Universal $\mathrm{SYBR}^{\circledR}$-Green Supermix (Bio-Rad Laboratories, Inc.) and measured by the CFX96 Touch PCR instrument (BioRad Laboratories, Inc.). Each qPCR run comprised a standard three-step PCR temperature protocol $\left(95^{\circ} \mathrm{C}\right.$ for $30 \mathrm{sec}$, followed by 40 cycles of $95^{\circ} \mathrm{C}$ for $10 \mathrm{sec}$ and $60^{\circ} \mathrm{C}$ for $20 \mathrm{sec}$ ), followed 
Table I. Antibodies used for the western blot analysis.

\begin{tabular}{|c|c|c|c|c|c|c|c|}
\hline \multicolumn{4}{|c|}{ Primary antibody } & \multicolumn{4}{|c|}{ Secondary antibody } \\
\hline Target & Supplier and cat. no. & Dil. & Inc. & Target & Supplier and cat. no. & Dil. & Inc. \\
\hline Bax & CS \#5023 & $1: 1,000$ & $\mathrm{ON} 4^{\circ} \mathrm{C}$ & Anti-rabbit & Dako P0448 & $1: 3,000$ & $1 \mathrm{~h} 4^{\circ} \mathrm{C}$ \\
\hline $\mathrm{Bcl}-2$ & CS \#3498 & $1: 1,000$ & $\mathrm{ON} 4^{\circ} \mathrm{C}$ & Anti-rabbit & Dako P0448 & $1: 3,000$ & $1 \mathrm{~h} 4^{\circ} \mathrm{C}$ \\
\hline Noxa & Thermo 1-41000 & $1: 1,000$ & $\mathrm{ON} 4^{\circ} \mathrm{C}$ & Anti-mouse & Dako P0447 & $1: 3,000$ & $1 \mathrm{~h} 4^{\circ} \mathrm{C}$ \\
\hline TRAIL-R2 & CS \#3696 & $1: 1,000$ & $\mathrm{ON} 4^{\circ} \mathrm{C}$ & Anti-rabbit & Dako P0448 & $1: 3,000$ & $1 \mathrm{~h} 4^{\circ} \mathrm{C}$ \\
\hline cPARP & Thermo 436400 & $1: 2000$ & $\mathrm{ON} 4^{\circ} \mathrm{C}$ & Anti-mouse & Dako P0447 & $1: 3,000$ & $1 \mathrm{~h} 4^{\circ} \mathrm{C}$ \\
\hline LC3BI-II & CS \#2775 & $1: 1,000$ & $\mathrm{ON} 4^{\circ} \mathrm{C}$ & Anti-rabbit & Dako P0448 & $1: 3,000$ & $1 \mathrm{~h} 4^{\circ} \mathrm{C}$ \\
\hline Survivin & CS \#2802 & $1: 1,000$ & $\mathrm{ON} 4^{\circ} \mathrm{C}$ & Anti-mouse & Dako P0447 & $1: 3,000$ & $1 \mathrm{~h} 4^{\circ} \mathrm{C}$ \\
\hline HSP90 & CS \#4877 & $1: 3,000$ & $\mathrm{ON} 4^{\circ} \mathrm{C}$ & Anti-rabbit & Dako P0448 & $1: 3,000$ & $1 \mathrm{~h} 4^{\circ} \mathrm{C}$ \\
\hline XIAP & CS \#2045 & $1: 3,000$ & $\mathrm{ON} 4^{\circ} \mathrm{C}$ & Anti-rabbit & Dako P0448 & $1: 3,000$ & $1 \mathrm{~h} 4^{\circ} \mathrm{C}$ \\
\hline Smad2 & sc-101153 & $1: 1,000$ & $\mathrm{ON} 4^{\circ} \mathrm{C}$ & Anti-mouse & Dako P0447 & $1: 3,000$ & $1 \mathrm{~h} 4^{\circ} \mathrm{C}$ \\
\hline Smad3 & sc-101154 & $1: 1,000$ & $\mathrm{ON} 4^{\circ} \mathrm{C}$ & Anti-mouse & Dako P0447 & $1: 3,000$ & $1 \mathrm{~h} 4^{\circ} \mathrm{C}$ \\
\hline$\gamma \mathrm{H} 2 \mathrm{AX}$ & CS \#2577 & $1: 1,000$ & $\mathrm{ON} 4^{\circ} \mathrm{C}$ & Anti-rabbit & Dako P0448 & $1: 3,000$ & $1 \mathrm{~h} 4^{\circ} \mathrm{C}$ \\
\hline$\beta$-actin & sc-47778 & $1: 10,000$ & $\mathrm{ON} 4^{\circ} \mathrm{C}$ & Anti-mouse & Dako P0447 & $1: 15,000$ & $1 \mathrm{~h} 4^{\circ} \mathrm{C}$ \\
\hline
\end{tabular}

TRAIL-R2, TNF-related apoptosis-inducing ligand receptor 2; cPARP, cleaved poly(ADP-ribose) polymerase (PARP); HSP90, heat shock protein 90; XIAP, X-linked inhibitor of apoptosis protein; $\gamma \mathrm{H} 2 \mathrm{AX}$; histone H2AX phosphorylation at serine 139; Dil., dilution; Inc, incubation; CS, Cell Signaling Technology, Inc.; Thermo, Thermo Fisher Scientific, Inc.; sc, Santa Cruz Biotechnology, Inc., ON, overnight (ON).

by a melting curve protocol to confirm a single gene-specific peak and to detect primer dimerization $\left(65-95^{\circ} \mathrm{C}\right)$. Relative quantification of expression levels was performed using the $\Delta \Delta \mathrm{Cq}$ method based on the geometric mean of the internal controls TATA-box binding protein and ribosomal protein lateral stalk subunit P0. The expression levels $(\mathrm{Cq})$ of the target genes were normalized to the reference genes ribosomal protein (RPL; cat. no. QT00075012), TATA box-binding protein (TBP; cat. no. QT00000721), and beta-2-microglobulin (B2M; cat. no. QT00088935) (all Qiagen $\mathrm{GmbH})(\Delta \mathrm{Cq})$, and the difference between the $\Delta \mathrm{Cq}$ value of the test and control samples produced the $\Delta \Delta \mathrm{Cq}$ value. Finally, the expression ratio was expressed as $2^{-\Delta \Delta \mathrm{Cq}}(21)$. The following QuantiTect primer assays (Qiagen $\mathrm{GmbH})$ were used for qPCR: Matrix metalloproteinases (MMP)2 (cat.no. QT00088396), MMP9 (cat. no.QT00040040), Bax (cat. no. QT00997381), Bcl-2 antagonist/killer-1 (Bak) (cat. no. QT00228508), Noxa (cat. no. QT00074438), and survivin (BIRC5) (cat. no. QT00081186). The following primers were used: Bcl-2 forward, 5'-GGAGGATTGTGGCCTTCTTTG-3' and reverse, 5'-GCCGGTTCAGGTACTCAGTCAT-3'; and TNF-related apoptosis-inducing ligand receptor 2 (TRAIL-R2) forward, 5'-ACCAACGAGCTGAAGCAGATG-3' and reverse, 5'-CAAGCAATGCCACTTTTGGA-3'. Untreated cells served as the reference.

Western blot analysis. Whole cell protein extracts were prepared $48 \mathrm{~h}$ post-bortezomib pretreatment and 5 Gy IR from spheroid cultures using a lysis buffer [50 mM Tris- $\mathrm{HCl}$ (pH 7.4), $150 \mathrm{mM} \mathrm{NaCl}, 1 \mathrm{mM} \mathrm{NaF}, 1 \mathrm{mM}$ ethylenediaminetetraacetic acid, $1 \%$ nonylphenol-40 and $\left.1 \mathrm{mM} \mathrm{Na} \mathrm{VO}_{4}\right]$, a protease and phosphatase inhibitor cocktail (PPC1010; Sigma-Aldrich; Merck KGaA) and subsequent sonication. Protein concentration was determined with the Pierce BCA Protein Assay kit (Thermo Fisher Scientific, Inc.). A total of $10-20 \mu \mathrm{g}$ of proteins were separated by $12 \%$ sodium dodecyl sulfate polyacrylamide gel electrophoresis and blotted on Amersham ${ }^{\mathrm{TM}}$ Protran $^{\mathrm{TM}}$ Premium $0.45 \mu \mathrm{M}$ nitrocellulose membranes (Cytiva). For microtubule-associated protein 1A/1B-light chain 3 (LC3)BI-II immunoblotting, the cells were treated with the lysosomal protease inhibitors E64d and pepstatin A $(10 \mu \mathrm{g} / \mathrm{ml}$; both Sigma-Aldrich; Merck KGaA), which were added to the cell culture medium to inhibit the autophagic flux and the degradation of LC3B-II, and improve the representation of the LC3B-II levels. All other blots were incubated with primary antibodies against the apoptotic markers Bax, Bcl-2, Noxa, TRAIL-R2, cleaved poly(ADP-ribose) polymerase (PARP), survivin and its downstream components heat shock protein 90 (HSP90), X-linked inhibitor of apoptosis protein (XIAP), smad 2 and smad 3, the DNA damage marker phospho-histone $\gamma \mathrm{H} 2 \mathrm{AX}$ and $\beta$-actin as the loading control. All antibody information, dilutions and incubation times are listed in Table I. Subsequently, the blots were incubated with a horseradish peroxidase-conjugated secondary antibody (Dako; Agilent Technologies, Inc.) for $1 \mathrm{~h}$ at room temperature, followed by overlay with Amersham ${ }^{\mathrm{TM}}$ $\mathrm{ECL}^{\mathrm{TM}}$ prime western blotting detection reagent (Cytiva). The resulting chemiluminescence signals were detected with the ChemiDocTouch Imaging System (Bio-Rad Laboratories, Inc.), and the images were processed with ImageLab 5.2 software (Bio-Rad Laboratories, Inc.).

Gene expression profiling. Gene expression profiling was performed using the Thermo Fisher Ion AmpliSeq RNA workflow. cDNA of $50 \mathrm{ng}$ RNA from chondrosarcoma spheroid cultures was synthesized using the SuperScript IV ${ }^{\text {Tм }}$ Vilo $^{\text {TM }}$ Master Mix (cat. no. 11756500; Thermo Fisher Scientific, Inc.; $25^{\circ} \mathrm{C}$ for $10 \mathrm{~min}, 50^{\circ} \mathrm{C}$ for $10 \mathrm{~min}, 85^{\circ} \mathrm{C}$ for $5 \mathrm{~min}$ and hold at $\left.10^{\circ} \mathrm{C}\right)$. AmpliSeq PCR and library preparation was performed 
using the Ion AmpliSeq Library Kit Plus and an Ion AmpliSeq RNA Panel (thermocycling conditions: $99^{\circ} \mathrm{C}$ for $2 \mathrm{~min}$, followed by 27 cycles of $99^{\circ} \mathrm{C}$ for $15 \mathrm{sec}$ and $60^{\circ} \mathrm{C}$ for $4 \mathrm{~min}$, and hold at $10^{\circ} \mathrm{C}$ ). Sequencing was performed on an Ion S5XL benchtop sequencer using the 540 Chip kit and the 200 base pair workflow (single-end; all Thermo Fisher Scientific, Inc.) to a total depth of $\sim 1$ million reads per sample. The amplicon sequencing depth was determined using the AmpliSeq RNA Ion Torrent Suite Plugin (version 4.4.0.4), and individual gene expression was calculated as amplicon reads per million total reads (RPM). The heatmap of the RNA sequencing data is presented as fold-change regarding the expression without IR (control) and 1 or $24 \mathrm{~h}$ post-IR of key player genes in terms of base excision repair (BER), mismatch mediated repair (MMR), nucleotide excision repair (NER), homology directed repair (HDR) and the nonhomologous end-joining (NHEJ). The sequencing coverage and the quality statistics of the AmpliSeq RNA sequencing are presented in Table SI. The corresponding raw data are presented in Table SII.

Immunocytochemistry. For immunocytochemical staining, chondrosarcoma cells were pretreated with the $\mathrm{IC}_{50}$ concentration of $5 \mathrm{nM}$ bortezomib for $24 \mathrm{~h}$ and irradiated with 0 (control) and $5 \mathrm{~Gy}$. At 1 and $24 \mathrm{~h}$ post-IR, the cells were fixed with $4 \%$ paraformaldehyde for $30 \mathrm{~min}$. The slides were incubated with a $\gamma \mathrm{H} 2 \mathrm{AX}$ antibody (Merck KGaA; cat. no. 05-636; 1:200) for $1 \mathrm{~h}$, the bridge antibody (Dako; cat. no. P0260; 1:200) for $30 \mathrm{~min}$, the polymer (rabbit-ON-rodent-horseradish peroxidase; Biocare Medical, LLC; RMR622H; ready to use) for 30 min and aminoethyl carbazole substrate chromogen (Dako; Agilent Technologies, Inc.) for $3 \mathrm{~min}$ (all room temperature). The reaction was stopped with phosphate-buffered saline, and hematoxylin core staining was performed. Images with x100 magnification were captured under an Olympus BX51 transmitted-light microscope (Olympus Corporation) and five areas were analyzed per slide.

Statistical analysis. Data are presented as the mean \pm SD or SEM as indicated. SigmaPlot 14.0 (Systat Software, Inc.) was used to generate the figures and graphs. Comparisons between untreated control, bortezomib- and IR-treated cells were performed by one way ANOVA followed by post hoc analysis using the Holm-Sidak test. Two-sided $\mathrm{P}<0.05$ was considered to indicate a statistically significant difference.

\section{Results}

Increasing IR intensities affect spheroid cultures. The preparation of 3D spheroid cultures using the hanging drop method is schematically presented in Fig. 1A. Chondrosarcoma cells (SW1353) and HCs formed clearly defined spheroids after 24-48 h.

Increasing IR doses only marginally reduced the viability of SW1353 3D spheroids at $3 \mathrm{~h}$; the reduction in $\mathrm{HC}$ viability appeared to be more pronounced compared with that observed in chondrosarcoma cells (Fig. 1B). Additionally, this downward trend of viability appeared also to be more pronounced in $\mathrm{HC}$ at $48 \mathrm{~h}$ compared with that in the chondrosarcoma cells. Treatment with the $\mathrm{IC}_{50}$ concentration of bortezomib significantly reduced viability in the two cell types (Fig. 1C).
Table II. Cell cycle distribution of chondrosarcoma cells $48 \mathrm{~h}$ after 5 and 20 Gy IR.

\begin{tabular}{lccc}
\hline & \multicolumn{3}{c}{ Cell cycle distribution at $48 \mathrm{~h}, \%$} \\
\cline { 2 - 4 } Group & $\mathrm{G}_{1}$ & $\mathrm{~S}$ & $\mathrm{G}_{2} / \mathrm{M}$ \\
\hline Ctrl & $55.9 \pm 7.8$ & $23.6 \pm 6.1$ & $20.8 \pm 6.7$ \\
Ctrl + 5 Gy IR & $52.5 \pm 13.5$ & $17.1 \pm 5.8$ & $30.4 \pm 9.1$ \\
Ctrl + 20 Gy IR & $24.5 \pm 2.7^{\text {a }}$ & $8.9 \pm 3.1^{\mathrm{a}}$ & $66.5 \pm 4.5^{\mathrm{a}}$ \\
Bor & $52.9 \pm 7.8$ & $26.5 \pm 6.2$ & $20.5 \pm 5.3$ \\
Bor + 5 Gy IR & $57.9 \pm 6.6$ & $16.6 \pm 4.6^{\mathrm{b}}$ & $25.5 \pm 10.1$ \\
Bor + 20 Gy IR & $47.5 \pm 9.7^{\mathrm{c}}$ & $7.5 \pm 1.4^{\mathrm{a}}$ & $45.0 \pm 9.2^{\mathrm{a}, \mathrm{d}}$ \\
\hline
\end{tabular}

${ }^{\mathrm{a}} \mathrm{P}<0.001 ;{ }^{\mathrm{b}} \mathrm{P}=0.026 ;{ }^{\mathrm{c}} \mathrm{P}=0.021$ vs. $\mathrm{ctrl}+20 \mathrm{~Gy} \mathrm{IR} ;{ }^{\mathrm{d}} \mathrm{P}=0.006$ vs. $\mathrm{ctrl}+$ 20 Gy IR; $n=5$; one-way ANOVA with Holm-Sidak test for multiple comparisons. Data are presented as the mean $\pm \mathrm{SD}$. IR, ionizing radiation; Ctrl, control; Bor, bortezomib.

Treatment with the respective $\mathrm{IC}_{50}$ concentrations (16) reduced the cell viability to $65.04 \pm 11.1 \%$ for SW1353 and to $60.37 \pm 6.10 \%$ for HC. Additional 5 or 20 Gy IR caused a further significant reduction to $58.61 \pm 12.24 \%$ for SW1353 and $33.77 \pm 4.56 \%$ for $\mathrm{HC}$, respectively. Therefore, $\mathrm{HC}$ exhibited higher sensitivity for both treatments compared with that of the chondrosarcoma cells.

Effects of IR on cell cycle distribution. Flow cytometry analysis was performed to determine the cell cycle profiles of chondrosarcoma spheroid cultures exposed to 5 and $20 \mathrm{~Gy} \mathrm{IR}$ with or without their respective $\mathrm{IC}_{50}$ concentrations of bortezomib for $48 \mathrm{~h}$ (16). Untreated cells were used as controls. The percentages and the corresponding significance levels of cells in various cell cycle phases are listed in Table II. Representative flow cytometry plots of untreated chondrosarcoma cells and those irradiated with $20 \mathrm{~Gy}$ are presented in Fig. 2A, and plots of the corresponding bortezomib-treated groups are presented in Fig. 2B. The graphical representations of the $G_{0} / G_{1}, S$ and $G_{2} / M$ values are shown in stacked bars. High-dose IR induced a significant increase in the number of cells in the $\mathrm{G}_{2} / \mathrm{M}$ phase compared with that in the control group, which was accompanied by a decrease in the number of $G_{1}$ and $S$ phase cells, indicating a persisting $G_{2} / M$ phase arrest at $48 \mathrm{~h}$ post-IR. Notably, a co-treatment with bortezomib reduced the $\mathrm{G}_{2} / \mathrm{M}$ phase arrest.

Induction of apoptosis by bortezomib and IR treatment. In order to investigate a possible sensitization to IR of chondrosarcoma cells by pretreatment with bortezomib, RT-qPCR was performed for the detection of the relative expression levels of the proapoptotic markers Bax and Bak, the antiapoptotic marker Bcl-2, the proapoptotic antagonist Noxa and the death receptor TRAIL-R2 (Fig. 3A). The mRNA levels of the proapoptotic genes Bax and Bak were significantly increased by bortezomib treatment compared with those in the control group. IR achieved higher or similar levels of Bax and Bak, respectively, compared with those in bortezomib-treated cells. Notably, co-treatment with bortezomib and IR decreased the Bax and Bak mRNA levels compared with those in cells 


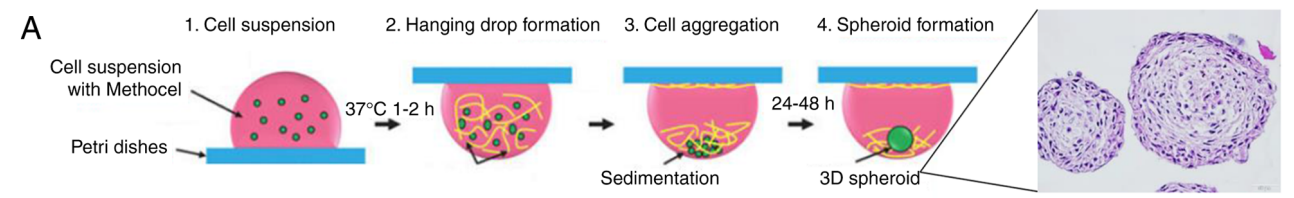

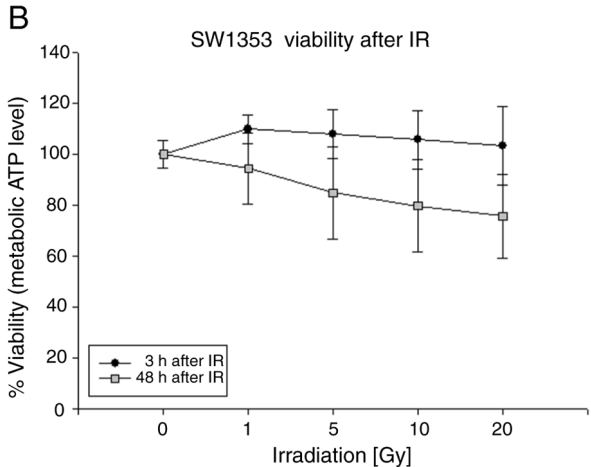

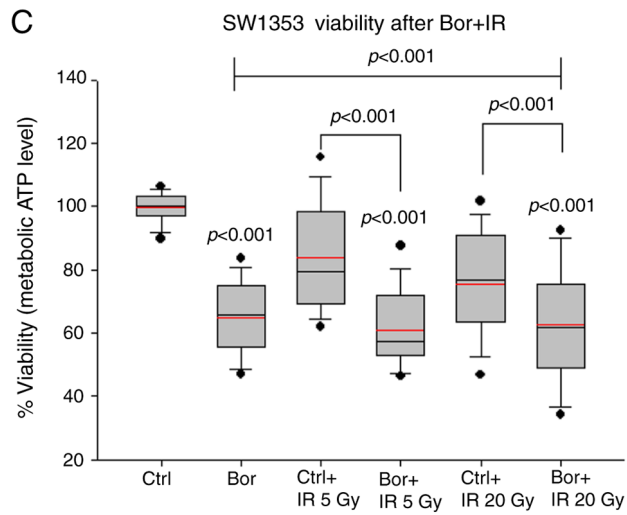

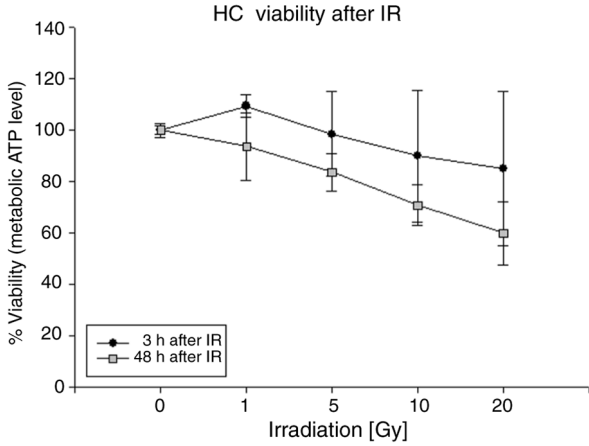

HC viability after Bor+IR

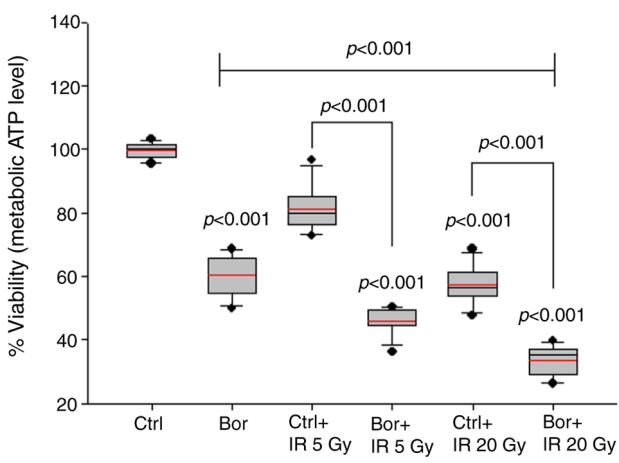

Figure 1. Chondrosarcoma 3D spheroid cultures. (A) The preparation of hanging drop 3D spheroid cultures and a representative image of H\&E staining (x400 magnification). (B) Effects of increasing IR doses on cell viability. (C) Effects of pretreatment with Bor and treatment with 5 and 20 Gy IR on the viability of SW1353 chondrosarcoma cells and HC. Data were normalized to untreated controls (0 Gy). Red lines represent mean values. HC, $\mathrm{n}=3$; SW1353, $\mathrm{n}=7$. IR, ionizing radiation; Ctrl, control; Bor, bortezomib; HC, healthy chondrocytes; 3D, three-dimensional.
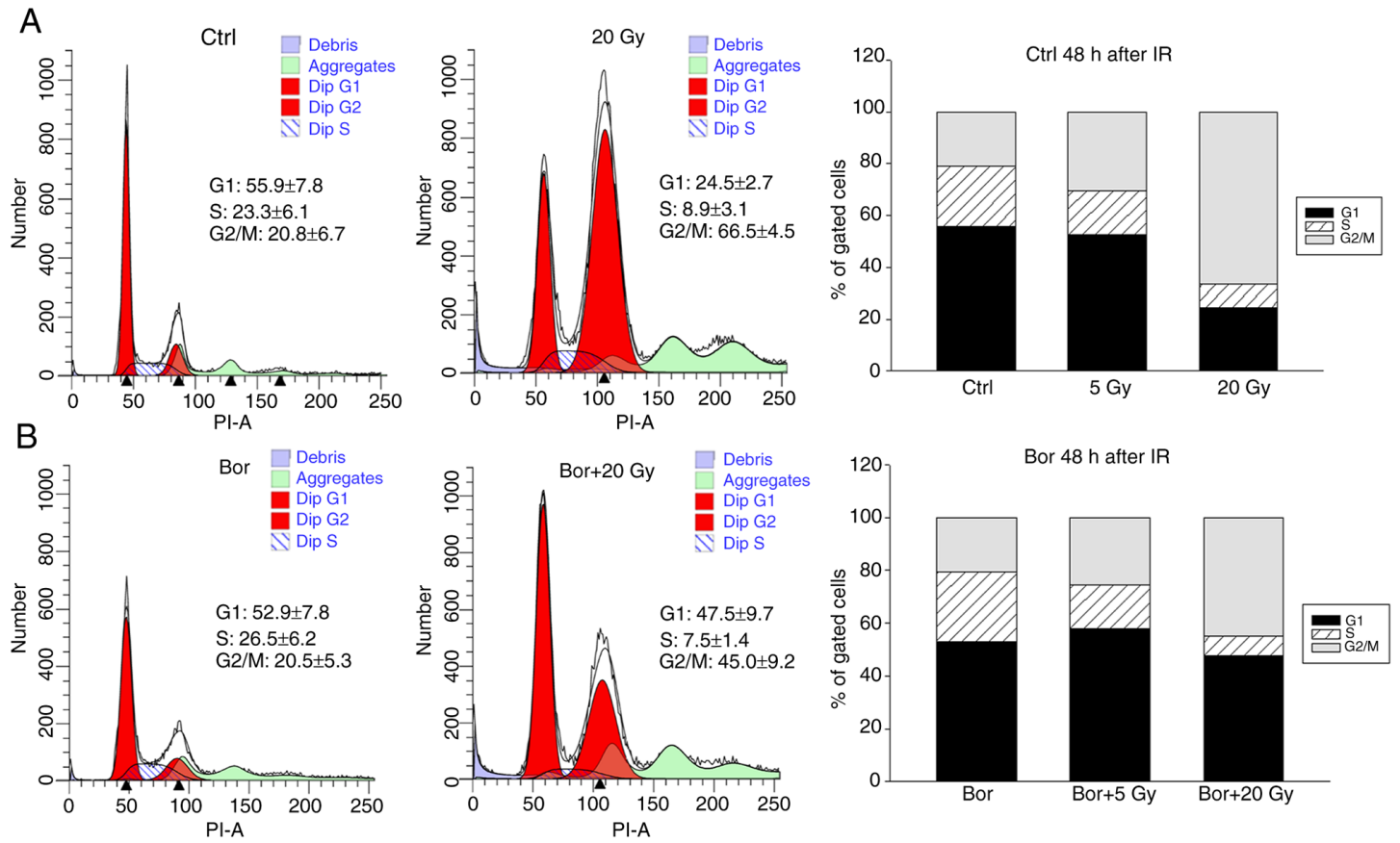

Figure 2. Effects of bortezomib and IR on the cell cycle distribution. (A and B) Representative flow cytometry cell cycle measurements (A) at $48 \mathrm{~h}$ post-IR exposure and (B) following co-treatment with bortezomib. Cell populations in the $\mathrm{G}_{0} / \mathrm{G}_{1}, \mathrm{~S}$ and $\mathrm{G}_{2} / \mathrm{M}$ phases are presented as the mean percentage of total cells $(n=5)$. IR caused a decrease in the number of cells in $\mathrm{G}_{1}$ (black) and $\mathrm{S}$ (dashed) phase, which was accompanied by a pronounced increase of cells in $\mathrm{G}_{2} / \mathrm{M} \mathrm{phase}$ (grey) ( $\mathrm{n}=5)$. IR, ionizing radiation; Ctrl, control; Bor, bortezomib. 

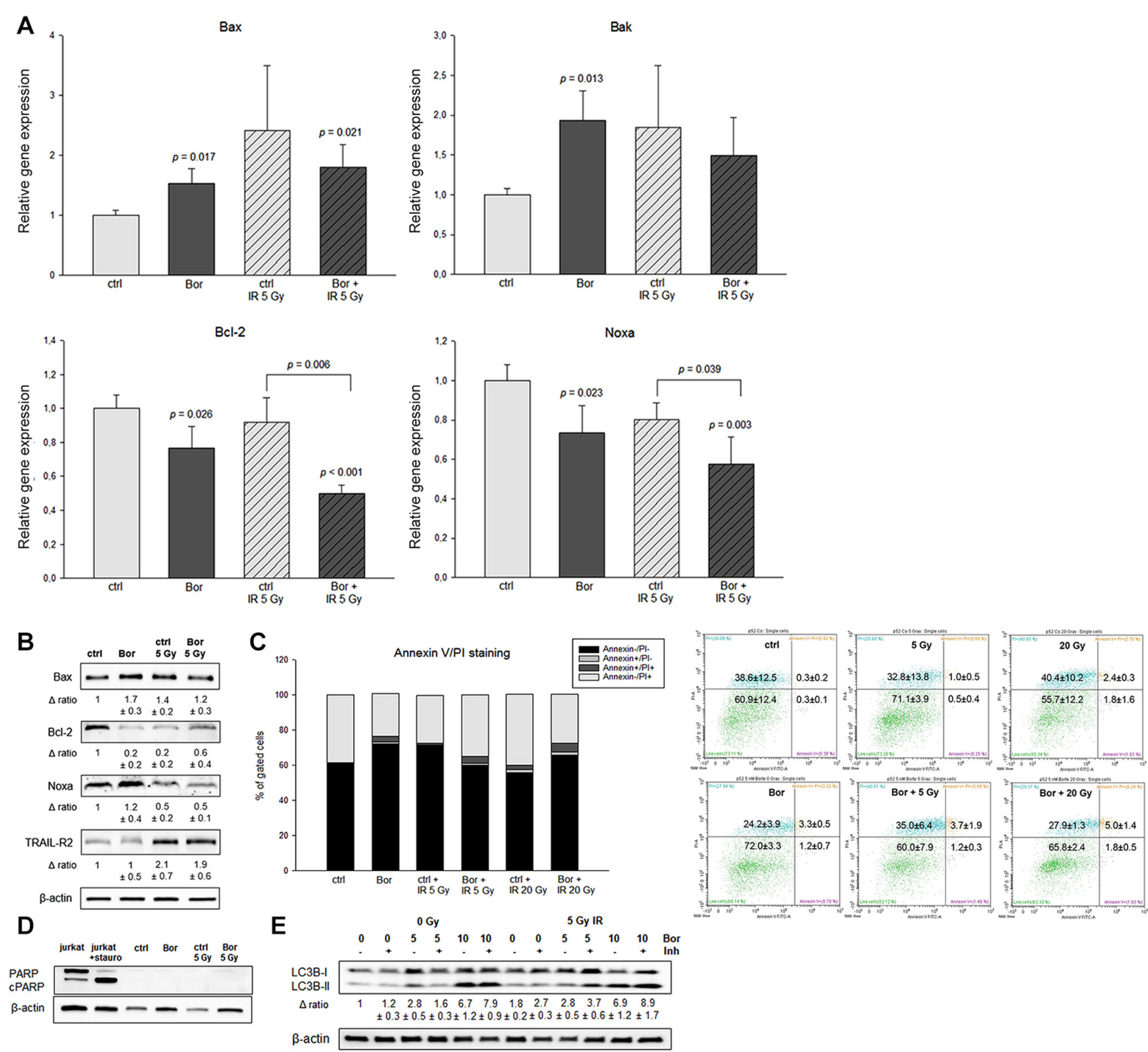

Figure 3. Effects of bortezomib and IR on apoptotic induction. (A) mRNA expression analysis of pro- and antiapoptotic markers was performed at $48 \mathrm{~h}$ post-IR The expression levels of the proapoptotic markers Bax and Bak were significantly increased by bortezomib treatment compared with those in the control group, and further enhanced by co-treatment with IR. In addition, bortezomib reduced the mRNA expression levels of Bcl-2 and Noxa compared with those in the control group. IR increased the relative expression levels of TRAIL-R2 ( $n=5$, mean \pm SEM). (B) Western blot analyses were used to verify the results at the protein level. $\beta$-actin was used as loading control $(\mathrm{n}=3$ ). (C) Annexin V/PI flow cytometric analysis at $48 \mathrm{~h}$ identified no significant changes following treatment with bortezomib or IR $(n=3)$. Representative measurements of the control and bortezomib +20 Gy groups are presented. (D) The PARP/cleaved PARP immunoblotting revealed no apoptotic induction. (E) Western blot analysis of the autophagy marker LC3BI-II in SW1353 cells treated with 5 and $10 \mathrm{nM}$ bortezomib for $24 \mathrm{~h}$. Lysosomal protease inhibitors blocked the autophagic flux and inhibited the degradation of LC3B-II. Additional IR induced no changes. $\beta$-actin was used as the loading control ( $\mathrm{n}=2$ ). IR, ionizing radiation; Ctrl, control; Bor, bortezomib; PARP, poly (ADP-ribose) polymerase; TRAIL-R2, TNF-related apoptosis-inducing ligand receptor 2; LC3, microtubule-associated protein 1A/1B-light chain 3; Inh, E64d and pepstatin A.

treated with IR alone. By contrast, bortezomib reduced the Bcl-2 and Noxa mRNA levels in non-irradiated cells, whereas in IR-treated cells, bortezomib significantly enhanced the 5 Gy-induced effect. In addition, IR increased the protein expression of TRAIL-R2 by 2 -fold (Fig. 3B). Annexin V/PI flow cytometric measurements revealed only a limited increase in the Annexin ${ }^{+} / \mathrm{PI}^{-}$cells between the untreated and the co-treatment groups Fig. 3C). In addition, there was no significant increase in early or late apoptotic cells between the control and Bor +20 Gy groups. The lack of apoptotic induction was further verified with a PARP/cleaved PARP immunoblot (Fig. 3D).

To determine the potential interplay between apoptosis and autophagy, immunoblotting of LC3B was performed.
As demonstrated in Fig. 3E, increasing concentrations of bortezomib significantly increased the expression levels of LC3B-II compared with those in the untreated cells. The lysosomal protease inhibitors E64d and pepstatin A inhibited the degradation of LC3B-II. IR, however, did not increase the expression of LC3B-II.

Expression of MMPs following bortezomib and IR treatment. Chondrosarcoma spheroid cultures were irradiated with 5 Gy following pretreatment with bortezomib, and total RNA was isolated and analyzed by qPCR. The results revealed that treatment with bortezomib or IR alone and the combined treatment significantly increased the expression levels of MMP2 and MMP9 compared with those in the control cells (Fig. 4A). 

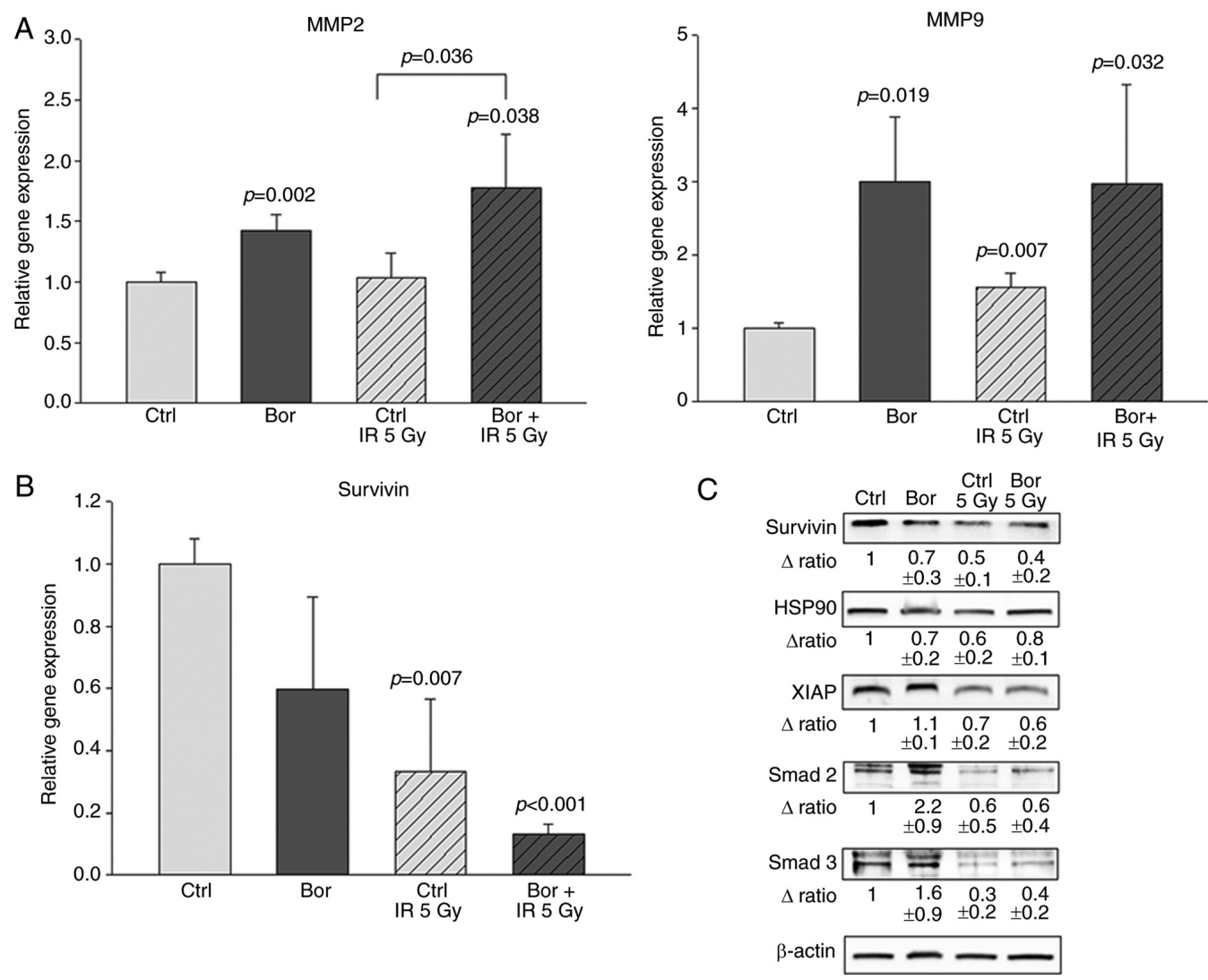

Figure 4. Signaling pathways affected by bortezomib and IR. (A) Bortezomib treatment significantly increased the mRNA expression levels of MMP2 and MMP9 compared with those in the control group, whereas irradiation exerted only a minor effect ( $\mathrm{n}=5$, mean \pm SEM). (B) mRNA expression analysis of survivin was performed at $48 \mathrm{~h}$ post-IR. A synergistic decrease in the survivin expression levels was observed when bortezomib and IR were combined. (C) Western blot analyses of survivin and its downstream proteins were used to verify the results at the protein level. $\beta$-actin was used as loading control ( $\mathrm{n}=3$, mean $\pm \mathrm{SEM}$ ). IR, ionizing radiation; Ctrl, control; Bor, bortezomib; MMP, matrix metalloproteinase; HSP90, heat shock protein 90; XIAP, X-linked inhibitor of apoptosis protein.

Synergistic effects of bortezomib and IR on the survivin signaling pathway. Following bortezomib treatment and IR, RNA was isolated from the cells, and the relative expression of the BIRC5 gene was determined using RT-qPCR. The expression levels of BIRC5 mRNA were significantly decreased by both bortezomib and IR treatment compared with those in the control group. In addition, co-treatment with bortezomib and IR resulted in an additive reduction (Fig. 4B). Western blot analyses of survivin and its downstream proteins were used to verify these results at the protein level (Fig. 4C). Compared with those in the control cells, treatment with bortezomib and IR reduced the protein expression levels of HSP90 in chondrosarcoma spheroid cultures, and the expression levels of XIAP, Smad 2 and Smad3 were reduced by IR (Fig. 4C).

DNA repair mechanisms following treatment with bortezomib and IR. To determine the potential involvement of bortezomib in radiation therapy resistance, DNA damage and the corresponding DNA repair genes were studied. The results demonstrated that at $24 \mathrm{~h}$ post-IR, not only the HDR, but also the NER pathway is positively regulated compared with those in the untreated controls (Fig. 5A). The number of double-strand breaks was determined by quantifying the levels of $\gamma \mathrm{H} 2 \mathrm{AX}$ at 1 and $24 \mathrm{~h}$ post-bortezomib pretreatment and IR (Fig. 5B). Chondrosarcoma cells exhibited a significant upregulation in $\gamma \mathrm{H} 2 \mathrm{AX}$ levels compared with those in the untreated control cells at $1 \mathrm{~h}$ post-IR independent of bortezomib, whereas at
$24 \mathrm{~h}$ post-IR, the levels of this indirect marker of DNA damage returned to the baseline. These observations were confirmed by immunohistochemical staining (Fig. 5C) and indicated rapid and efficient DNA damage repair in chondrosarcoma cells.

\section{Discussion}

In patients with chondrosarcoma with unfavorable initial characteristics, a high grade and incomplete resection, postoperative radiotherapy is an expedient option; it reduces the risk of local recurrence and improves 5-year disease-free survival from 64.2 to $71.8 \%$ (22). Chondrosarcomas exhibit variable response to irradiation, possibly due to their strong genetic heterogeneity, which is also evident in different chondrosarcoma cell lines $(23,24)$. In this context, it is particularly important to gain new insights into the underlying tumor biology of chondrosarcoma. The use of 3D spheroid cultures represents the in vivo environment more accurately compared with conventional 2D monolayer cultures; 3D cultivation mimics the architecture of the donor tissue and enables both cell-cell and cell-matrix interactions (25). Therefore, the present study utilized the hanging drop 3D spheroid model. The viability of the two cell types used in the present study was only moderately affected by increasing IR intensity. Co-treatment with bortezomib appeared to be the main trigger for the observed decrease in the viability of chondrosarcoma 
A

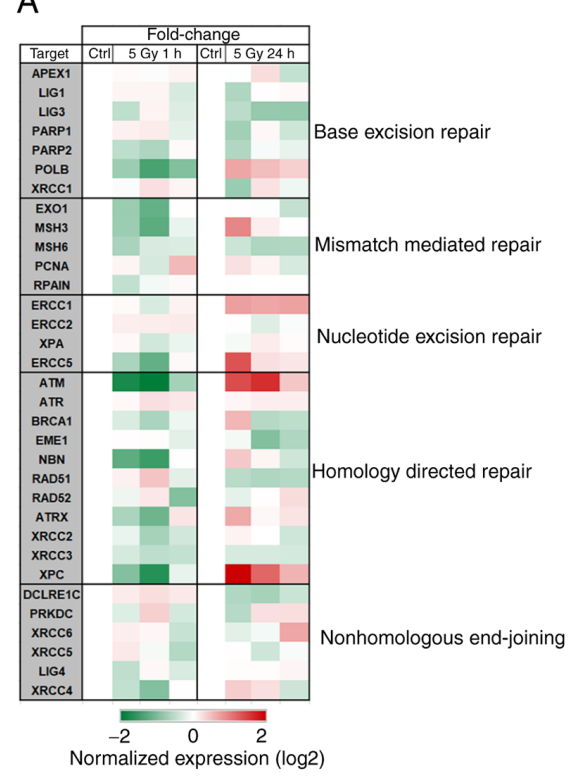

B

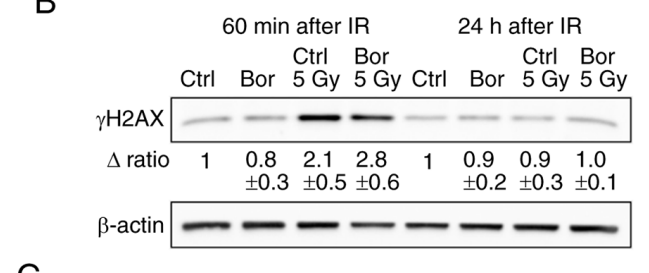

C

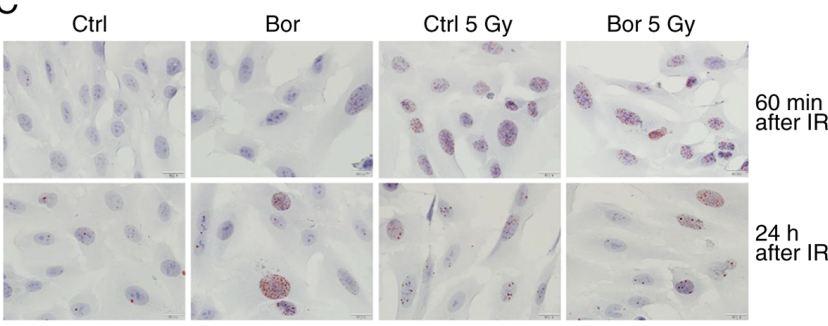

Figure 5. Effects of bortezomib and IR on DNA damage. (A) Heatmap of RNA sequencing data of the key genes involved in DNA repair mechanism pathways. The results are presented as fold-change compared with the untreated controls $(\mathrm{n}=3)$. (B) Following 24-h pretreatment with bortezomib and an additional $1 \mathrm{~h}$ post-IR, chondrosarcoma cells exhibited a significant increase in $\gamma \mathrm{H} 2 \mathrm{AX}$ protein phosphorylation levels compared with those in the control group. At $24 \mathrm{~h}$ post-IR, this DNA damage marker returned to baseline levels. (C) Immunohistochemical staining of $\gamma \mathrm{H} 2 \mathrm{AX}$ at 1 and $24 \mathrm{~h}$ post-IR. IR, ionizing radiation; Ctrl, control; Bor, bortezomib; $\gamma \mathrm{H} 2 \mathrm{AX}$, histone $\mathrm{H} 2 \mathrm{AX}$ phosphorylation at serine 139.

cells. During radiotherapy, the co-treatment may positively affect the therapeutic efficacy of 5 Gy IR.

DNA structure checkpoints are necessary in the regulation of the cell cycle; they cause cell cycle arrest in response to incomplete replication or DNA damage. Known as the 'restriction point' in human cells, this point is defined as the moment after which cells are committed to entering and progressing through the cell cycle independent of signals from the environment (26). The $\mathrm{G}_{2} / \mathrm{M}$ phase delay in tumor cells following IR enables sufficient time for repair processes and ensures cell survival of otherwise lethal DNA damage (27). A previous study has reported that X-ray irradiation induces a $\mathrm{G}_{2} / \mathrm{M}$ phase arrest in HeLa cancer cells and is associated with the increase of the expression levels of checkpoint kinase 1 and the reduction of those of cyclin-dependent kinase $1(28,29)$. The results of the present study revealed that both untreated and bortezomib pretreated spheroid cultures exhibited $\mathrm{G}_{2} / \mathrm{M}$ accumulation following IR. This replication arrest may enable the chondrosarcoma cells to regenerate more efficiently. The changes in cell cycle distribution observed in other cell systems following bortezomib treatment alone, however, were not be detected in chondrosarcoma cells in the present study $(30,31)$.

An important indicator of possible damage in tumor cells is the induction of apoptosis. Bcl-2 family proteins exert undergo pro- or anti-apoptotic activities and regulate the mitochondrial apoptosis pathway by controlling outer mitochondrial membrane permeability (32). Reacting to a variety of types of damage or stress, certain Bcl-2 family members induce Bax or Bak proapoptotic protein activation at the mitochondrion (32). Bax and Bak homo-oligomerize and function in the outer mitochondrial membrane in pore formation, via which proapoptotic molecules escape; this results in the development of the morphological characteristics of apoptosis, including DNA laddering, condensed nuclei and phosphatidylserine exposure to the outer plasma membrane leaflet (33). In the present study, in chondrosarcoma cells, both bortezomib treatment and IR increased the expression levels of Bax and Bak compared with those in the control group. Notably, the combination of the two treatments did not lead to a synergistic enhancement of these effects, whereas the reduction in the expression levels of the antiapoptotic protein $\mathrm{Bcl}-2$ was significantly enhanced by the co-treatment with IR and bortezomib. This was particularly notable at the protein level. Noxa is an indirect activator of apoptosis, as it only neutralizes the prosurvival members of the Bcl-2 family Mcl1 and Bcl-2, preventing them from regulating the levels of Bax and Bak (34). The levels of Noxa were also significantly decreased in the spheroid cultures by co-treatment with IR and bortezomib compared with those in the control cells in the present study. As a tumor necrosis factor receptor superfamily protein, which is mainly localized in the cell membrane, TRAIL-R2 triggers caspase- 8 activation in response to anticancer drug treatment (35). The irradiation intensity of $5 \mathrm{~Gy}$ increased the protein expression levels of TRAIL-R2 2-fold compared what that in the controls. Despite the regulation of these apoptotic genes, only a small increase in the percentage of late apoptotic cells (Annexin ${ }^{+} / \mathrm{PI}^{-}$) was observed $48 \mathrm{~h}$ after IR and/or bortezomib treatment.

Autophagy has been discussed in the literature in recent years as an alternative cell death mechanism to apoptosis $(36,37)$. During autophagy, the microtubule-associated protein LC3B is localized on the membranes, resulting in autophagosome membrane formation, and the level of LC3B-II is a marker for autophagosome formation (38). Bortezomib increases the autophagy-associated protein expression levels, including that of as autophagy-related 5/12, LC3I-II and Beclin in chondrosarcoma cells (16). However, an additional increase 
in the levels of autophagy-associated proteins by IR was not observed in the present study.

MMP2 and MMP9 are cancer-associated, secreted, zinc-dependent endopeptidases, the secretion of which is elevated in several types of human cancer such as liposarcoma, cervical, pancreatic or prostate cancer; their elevated expression has been associated with a poor prognosis (39). In the present study, bortezomib treatment significantly increased the expression levels of MMP2 and MMP9 compared with those in the untreated control cells, whereas irradiation exerted limited effects.

The results of the present study demonstrated the synergistic effects of bortezomib and IR on the mRNA and protein levels of survivin. Survivin is the smallest member of the inhibitor of apoptosis protein family (IAPs), and serves vital roles in the regulation of cell division and the inhibition of apoptosis via caspase activation blockade $(40,41)$. Survivin has been highlighted vital for chondrosarcoma survival using small interfering RNA screening for 51 apoptosis-related genes in chondrosarcoma cells (42). The molecular chaperone Hsp90 participates in importing various client proteins to the mitochondria and has been demonstrated to be associated with survivin and other IAPs (43). Compared with that in the control cells, treatment with bortezomib and IR reduced the protein expression of HSP90 in chondrosarcoma spheroid cultures and thus may have impeded the survivin pathway. As a potent inhibitor of apoptosis, XIAP interacts directly with caspases to inhibit them (44). The reduced expression levels of survivin and XIAP caused by IR in the present study may lead to the induction of apoptosis. TGF- $\beta$ and its signaling effectors smad 2 and smad 3 are key factors in controlling tumor cell proliferation and differentiation (45), and repress survivin expression at the transcriptional level (46). Both smad 2 and smad 3 exhibited a significant reduction in their protein expression levels following IR compared with those in the control group. Thus, the inhibition of the entire survivin pathway was demonstrated, especially after IR, in the present study.

Another important aspect of cancer therapy is the regeneration behavior of tumor cells after radiotherapy. Radiation-induced cell death mostly occurs due to DNA damage, especially due to double-strand breaks (47). The gene expression profiling data in the present study revealed that, supplementary to the HDR pathway, as described in the literature for other types of cancer such as breast or ovarian cancer (48), the NER pathway, with the key players excision repair cross-complementation group 1 and 5, is also activated in chondrosarcoma cells after IR. Although cell viability was decreased both after treatment with bortezomib and after irradiation compared with that in untreated cells, increased DNA repair following treatment was observed in the present study. Since the levels of $\gamma \mathrm{H} 2 \mathrm{AX}$ are associated with DNA double-strand breaks, it is the most common surrogate marker to study DNA damage induction and the subsequent repair of the DNA lesion (49). In the present study, comparative analysis at 1 and $24 \mathrm{~h}$ post-IR indicated efficient DNA repair in human chondrosarcoma cells, returning to baseline levels within $24 \mathrm{~h}$.

In conclusion, the results of the present study demonstrated that co-treatment with bortezomib improved the radiation sensitivity of chondrosarcoma cells to a limited extent. The inhibition of the survivin signaling pathway revealed a novel interesting aspect in the tumor biology of chondrosarcoma 3D spheroid cultures and may provide a future option for clinical exploitation.

\section{Acknowledgements}

Not applicable.

\section{Funding}

The current study was supported by the Austrian Science Foundation (grant no. P32103-B) and the Ludwig Boltzmann Institute for Arthritis and Rehabilitation.

\section{Availability of data and materials}

All data generated or analyzed during this study are included in this published article.

\section{Authors' contributions}

BL conceived and supervised the study. DGl, SKG and NE performed the experiments. BL, DGl, BSF, BR, NE, AL and DGe analyzed and interpreted the data. DGl, NE and BR confirm the authenticity of all the raw data. BL, SKG, and DGe drafted and revised the manuscript. BR, AL and DGe provided technical support. All authors read and approved the final manuscript.

\section{Ethics approval and consent to participate}

Not applicable.

\section{Patient consent for publication}

Not applicable.

\section{Competing interests}

The authors declare that they have no competing interests.

\section{References}

1. Fletcher CD, Bridge JA, Hogendoorn PC and Mertens F (eds). World Health Organization: World Health Organization Classification of Tumours of Soft Tissue and Bone. 4th edition. IARC Press, Lyon, pp264-274, 2013.

2. Chow WA: Chondrosarcoma: biology, genetics, and epigenetics. F1000Res 7: F1000 Faculty Rev-1826, 2018.

3. Hug EB, Loredo LN, Slater JD, DeVries A, Grove RI, Schaefer RA, Rosenberg AE and Slater JM: Proton radiation therapy for chordomas and chondrosarcomas of the skull base. J Neurosurg 91: 432-439, 1999.

4. Hauptman JS, Barkhoudarian G, Safaee M, Gorgulho A, Tenn S, Agazaryan N, Selch M and De Salles AA: Challenges in linear accelerator radiotherapy for chordomas and chondrosarcomas of the skull base: Focus on complications. Int J Radiat Oncol Biol Phys 83: 542-551, 2012.

5. Bloch $\mathrm{O}$ and Parsa AT: Skull base chondrosarcoma: Evidence-based treatment paradigms. Neurosurg Clin N Am 24: 89-96, 2013.

6. Debus J, Schulz-Ertner D, Schad L, Essig M, Rhein B, Thillmann CO and Wannenmacher M: Stereotactic fractionated radiotherapy for chordomas and chondrosarcomas of the skull base. Int J Radiat Oncol Biol Phys 47: 591-596, 2000. 
7. De Amorim Bernstein K, Liebsch N, Chen YL, Niemierko A, Schwab JH, Raskin K, Lozano-Calderon SA, Cote G, Harmon DC, Choy E, et al: Clinical outcomes for patients after surgery and radiation therapy for mesenchymal chondrosarcomas. J Surg Oncol 114: 982-986, 2016.

8. De Amorim Bernstein K and DeLaney T: Chordomas and chondrosarcomas-The role of radiation therapy. J Surg Oncol 114: 564-569, 2016.

9. DeLaney TF, Liebsch NJ, Pedlow FX, Adams J, Weyman EA, Yeap BY, Depauw N, Nielsen GP, Harmon DC, Yoon SS, et al: Long-term results of Phase II study of high dose photon/proton radiotherapy in the management of spine chordomas, chondrosarcomas, and other sarcomas. J Surg Oncol 110: 115-122, 2014.

10. Indelicato DJ, Rotondo RL, Begosh-Mayne D, Scarborough MT, Gibbs CP, Morris CG and Mendenhall WM: A prospective outcomes study of proton therapy for chordomas and chondrosarcomas of the spine. Int J Radiat Oncol Biol Phys 95: 297-303, 2016.

11. Holtzman AL, Rotondo RL, Rutenberg MS, Indelicato DJ, Mercado CE, Rao D, Tavanaiepour D, Morris CG, Louis D, Flampouri S, et al: Proton therapy for skull-base chondrosarcoma, a single-institution outcomes study. J Neurooncol 142: $557-563,2019$.

12. Wu YH, Wu WS, Lin LC, Liu CS, Ho SY, Wang BJ, Huang BM, Yeh YL, Chiu HW, Yang WL, et al: Bortezomib enhances radiosensitivity in oral cancer through inducing autophagy-mediated TRAF6 oncoprotein degradation. J Exp Clin Cancer Res 37: 91, 2018.

13. Cui H, Qin Q, Yang M, Zhang H, Liu Z, Yang Y, Chen X, Zhu H, Wang D, Meng C, et al: Bortezomib enhances the radiosensitivity of hypoxic cervical cancer cells by inhibiting HIF-1 $\alpha$ expression. Int J Clin Exp Pathol 8: 9032-9041, 2015.

14. Cacan E, Spring AM, Kumari A, Greer SF and Garnett-Benson C: Combination treatment with sublethal ionizing radiation and the proteasome inhibitor, bortezomib, enhances death-receptor mediated apoptosis and anti-tumor immune Attack. Int J Mol Sci 16: 30405-30421, 2015.

15. Wang D, Qin Q, Jiang QJ and Wang DF: Bortezomib sensitizes esophageal squamous cancer cells to radiotherapy by suppressing the expression of HIF-1 $\alpha$ and apoptosis proteins. J XRay Sci Technol 24: 639-646, 2016

16. Lohberger B, Steinecker-Frohnwieser B, Stuendl N, Kaltenegger H, Leithner A and Rinner B: The proteasome inhibitor bortezomib affects chondrosarcoma cells via the mitochondria-caspase dependent pathway and enhances death receptor expression and autophagy. PLoS One 11: e0168193, 2016.

17. Ryu NE, Lee SH and Park H: Spheroid culture system methods and applications for mesenchymal stem cells. Cells 8: E1620, 2019.

18. Edmondson R, Broglie JJ, Adcock AF and Yang L: Three-dimensional cell culture systems and their applications in drug discovery and cell-based biosensors. Assay Drug Dey Technol 12: 207-218, 2014

19. Khaitan D and Dwarakanath BS: Multicellular spheroids as an in vitro model in experimental oncology: Applications in translational medicine. Expert Opin Drug Discov 1: 663-675, 2006.

20. Dolznig H, Rupp C, Puri C, Haslinger C, Schweifer N, Wieser E, Kerjaschki D and Garin-Chesa P: Modeling colon adenocarcinomas in vitro a 3D co-culture system induces cancer-relevant pathways upon tumor cell and stromal fibroblast interaction. Am J Pathol 179: 487-501, 2011

21. Livak KJ and Schmittgen TD: Analysis of relative gene expression data using real-time quantitative PCR and the 2(-Delta Delta C(T)) method. Methods 25: 402-408, 2001.

22. Terlizzi M, Le Pechoux C, Salas S, Rapeaud E, Lerouge D, Sunyach MP, Vogin G, Sole CV, Zilli T, Lutsyk M, et al: Postoperative radiotherapy in patients with extracranial chondrosarcoma, a joint study of the French Sarcoma Group and Rare Cancer Network. Int J Radiat Oncol Biol Phys 107: 726-735, 2020

23. Girard N, Lhuissier E, Aury-Landas J, Cauvard O, Lente M, Boittin M, Baugé $\mathrm{C}$ and Boumédiene K: Heterogeneity of chondrosarcomas response to irradiations with X-rays and carbon ions: A comparative study on five cell lines. J Bone Oncol 22: 100283, 2020

24. de Jong Y, Ingola M, Briaire-de Bruijn IH, Kruisselbrink AB, Venneker S, Palubeckaite I, Heijs BP, Cleton-Jansen AM, Haas RL and Bovée JV: Radiotherapy resistance in chondrosarcoma cells; a possible correlation with alterations in cell cycle related genes. Clin Sarcoma Res 9: 9, 2019.

25. Ravi M, Paramesh V, Kaviya SR, Anuradha E and Solomon FD 3D cell culture systems: Advantages and applications. J Cell Physiol 230: 16-26, 2015
26. Barnum KJ and O'Connell MJ: Cell cycle regulation by checkpoints. Methods Mol Biol 1170: 29-40, 2014.

27. Krempler A, Deckbar D, Jeggo PA and Löbrich M: An imperfect G2M checkpoint contributes to chromosome instability following irradiation of $S$ and $\mathrm{G} 2$ phase cells. Cell Cycle 6: 1682-1686, 2007.

28. Zhao H, Zhuang Y, Li R, Liu Y, Mei Z, He Z, Zhou F and Zhou Y: Effects of different doses of X-ray irradiation on cell apoptosis, cell cycle, DNA damage repair and glycolysis in HeLa cells. Oncol Lett 17: 42-54, 2019.

29. Marples B, Wouters BG and Joiner MC: An association between the radiation-induced arrest of G2-phase cells and low-dose hyper-radiosensitivity: A plausible underlying mechanism? Radiat Res 160: 38-45, 2003

30. Xing SS, Shen CC, Godard MP, Wang JJ, Yue YY, Yang ST, Zhao Q, Zhang SB, Wang TX, Yang XL, et al: Bortezomib inhibits $\mathrm{C} 2 \mathrm{C} 12$ growth by inducing cell cycle arrest and apoptosis. Biochem Biophys Res Commun 445: 375-380, 2014.

31. Gu JJ, Kaufman GP, Mavis C, Czuczman MS and HernandezIlizaliturri FJ: Mitotic catastrophe and cell cycle arrest are alternative cell death pathways executed by bortezomib in rituximab resistant B-cell lymphoma cells. Oncotarget 8: 12741-12753, 2017.

32. Edlich F: BCL-2 proteins and apoptosis: Recent insights and unknowns. Biochem Biophys Res Commun 500: 26-34, 2018

33. Brunelle JK and Letai A: Control of mitochondrial apoptosis by the Bcl-2 family. J Cell Sci 122: 437-441, 2009.

34. Guikema JE, Amiot $M$ and Eldering E: Exploiting the pro-apoptotic function of NOXA as a therapeutic modality in cancer. Expert Opin Ther Targets 21: 767-779, 2017.

35. Yamamoto Y, Tomiyama A, Sasaki N, Yamaguchi H, Shirakihara T, Nakashima K, Kumagai K, Takeuchi S, Toyooka T, Otani N, et al: Intracellular cholesterol level regulates sensitivity of glioblastoma cells against temozolomide-induced cell death by modulation of caspase- 8 activation via death receptor 5-accumulation and activation in the plasma membrane lipid raft, Biochem Biophys Res Commun 495: 1292e1299, 2018.

36. Tompkins KD and Thorburn A: Regulation of apoptosis by autophagy to enhance cancer therapy. Yale J Biol Med 92: 707-718, 2019.

37. Tilija Pun N, Jang WJ and Jeong CH: Role of autophagy in regulation of cancer cell death/apoptosis during anti-cancer therapy: Focus on autophagy flux blockade. Arch Pharm Res 43: 475-488, 2020.

38. Mizushima $\mathrm{N}$ and Yoshimori T: How to interpret LC3 immunoblotting. Autophagy 3: 542-545, 2007.

39. Roomi MW, Monterrey JC, Kalinovsky T, Rath M and Niedzwiecki A: Patterns of MMP-2 and MMP-9 expression in human cancer cell lines. Oncol Rep 21: 1323-1333, 2009.

40. Brady SW, Zhang J, Tsai MH and Yu D: PI3K-independent mTOR activation promotes lapatinib resistance and IAP expression that can be effectively reversed by mTOR and Hsp90 inhibition. Cancer Biol Ther 16: 402-411, 2015.

41. Chen X, Duan N, Zhang C and Zhang W: Survivin and tumorigenesis: Molecular mechanisms and therapeutic strategies. J Cancer 7: 314-323, 2016.

42. de Jong Y, van Oosterwijk JG, Kruisselbrink AB, Briaire-de Bruijn IH, Agrogiannis G, Baranski Z, Cleven AH, Cleton-Jansen AM, van de Water B, Danen EH, et al: Targeting survivin as a potential new treatment for chondrosarcoma of bone. Oncogenesis 5: e222, 2016.

43. Kang BH, Plescia J, Song HY, Meli M, Colombo G, Beebe K, Scroggins B, Neckers L and Altieri DC: Combinatorial drug design targeting multiple cancer signaling networks controlled by mitochondrial Hsp90. J Clin Invest 119: 454-464, 2009.

44. Du J, Kelly AE, Funabiki H and Patel DJ: Structural basis for recognition of H3T3ph and Smac/DIABLO N-terminal peptides by human Survivin. Structure 20: 185-195, 2012.

45. Derynck R, Akhurst RJ and Balmain A: TGF-beta signaling in tumor suppression and cancer progression. Nat Genet 29: 117-129, 2001

46. Song K, Shankar E, Yang J, Bane KL, Wahdan-Alaswad R and Danielpour D: Critical role of a survivin/TGF- $\beta / \mathrm{mTORC} 1$ axis in IGF-I-mediated growth of prostate epithelial cells. PLoS One 8: e61896, 2013.

47. Khanna KK and Jackson SP: DNA double-strand breaks: Signaling, repair and the cancer connection. Nat Genet 27: 247-254, 2001.

48. Fontana AO, Augsburger MA, Grosse N, Guckenberger M, Lomax AJ, Sartori AA and Pruschy MN: Differential DNA repair pathway choice in cancer cells after proton- and photon-irradiation. Radiother Oncol 116: 374-380, 2015.

49. Sharma A, Singh K and Almasan A: Histone H2AX phosphorylation: A marker for DNA damage. Methods Mol Biol 920: 613-626, 2012.

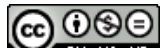

This work is licensed under a Creative Commons

Attribution-NonCommercial-NoDerivatives 4.0 International (CC BY-NC-ND 4.0) License. 